\title{
Full-Scale Co-Composting of Hair Wastes from the Leather Manufacturing Industry and Sewage Sludge
}

Raquel Barrena ${ }^{a}$, Estel·la Pagans ${ }^{\mathrm{a}, \mathrm{b}}$, Felícitas Vázquez ${ }^{\mathrm{a}, \mathrm{b}}$, Adriana Artola ${ }^{\mathrm{a}, \mathrm{c}}$ and Antoni Sánchez ${ }^{\mathrm{a}, \mathrm{c},{ }^{*}}$

${ }^{a}$ Escola Universitària Politècnica del Medi Ambient

Universitat Autònoma de Barcelona

Rbla Pompeu Fabra 1, 08100-Mollet del Vallès (Barcelona, Spain)

Present address:

${ }^{\mathrm{b}} \mathrm{GIRO}$ Centre Tecnològic

Rbla. Pompeu Fabra 1, 08100-Mollet del Vallès (Barcelona, Spain)

'Departament d'Enginyeria Química, Escola Tècnica Superior d'Enginyeria, Universitat Autònoma de Barcelona,

08193 Cerdanyola del Vallès, Barcelona, Spain.

${ }^{*}$ Corresponding Author: Dr. Antoni Sánchez

FAX: (34) 935812013

E-mail: antoni.sanchez@uab.es 


\section{Abstract}

A full-scale co-composting experiment using hair wastes from the leather manufacturing industry and sewage sludge as co-substrates was carried out with the aim of producing compost that may be used as an organic amendment in agriculture. A 1:1 weight ratio of hair wastes and sewage sludge was used based on experiments at smaller scale. The resulting mixture was then amended with pruning wastes acting as bulking agent in a 1:1 volumetric ratio (mixture:pruning wastes). The experiment was carried out using the windrow composting technology with a weekly turning frequency. Thermophilic range of temperature was quickly achieved and maintained for more than 8 weeks. This fact ensured the sanitation of the compost according to international requirements. Additionally, the quality of the product obtained expressed in stability terms was very high (Selfheating test grade: $\mathrm{V}$; respiration index: $0.83 \mathrm{mg} \mathrm{O}_{2}$ per gram of organic matter per hour). The nitrogen content in the final product was also high (5.6\%, dry basis). In conclusion, the recycling of hair wastes produced in the leather manufacturing industry using the composting technology is feasible and a valuable organic fertilizer may be obtained. 


\section{Introduction}

The leather and hide industry in Spain plays an important role in the economy of the country. Spain is the European leader in the tanning sector with a production of $27,473 \mathrm{~m}^{2}$ of cattle/calf and $16,742 \mathrm{~m}^{2}$ of goat/sheep in 2003 , representing more than $15 \%$ of the total European Union production (Euroleather 2005). The region with the highest tanning activity is located in Catalonia (northeast of Spain) near the city of Igualada, where an important sector is dedicated to the manufacturing of leather from cow hide (AlICA 2005).

The tannery industry is responsible for the production of high amounts of wastewater with high levels of pollutants such as COD or Cr. There is abundant literature about the treatment of this wastewater using different technologies, such as physico-chemical treatments (Murugananthan et al. 2004; Song et al. 2004) or biological treatments (Boshoff et al. 2004; Farabegoli et al. 2004). However, to our knowledge, there are only few studies on the specific treatment of the solid wastes generated in the tannery sector, such as chrome shavings (Cabeza et al. 1998) or unhairing wastes. They are usually considered and treated as wastewater (Vidal et al. 2004).

Land application for the disposal of tannery and other leather wastes has been widely practiced, but few landfill sites willing to accept them can be found nowadays and the cost of transportation and disposal increases. From a practical, economical and environmental point of view, recycling of solid wastes from the tannery industry seems the most sustainable way to manage these materials. 
These wastes are characterized by their high content of organic matter and nitrogen. Therefore, composting may be the technology of choice for the transformation of tannery solid wastes into a compost material with a high agronomical value, specially in the case of unhairing wastes, where the concentration of heavy metals is low (AllCA 2005). Composting is a biotechnological process by which different microbial communities degrade organic matter into simpler nutrients. It is an aerobic process, which requires oxygen for microbial biodegradation, and optimal moisture and porosity. Temperature, oxygen and moisture content are often selected as the control variables in the composting process (Haug 1993). Moreover, the possibility of using a material produced by composting as an organic amendment depends on the quality of the product in relation to its nutrients content (Wong et al. 1999) and its maturity and stability (Wang et al. 2004).

The aim of this work is then to present the composting process as an alternative management technology for the treatment of hair wastes of the tannery industry generated in the leather production. Sewage sludge is selected as a complementary waste to carry out the co-composting process. Technical aspects related to the sanitation of the compost and the quality and characteristics of the final product are also discussed. 


\section{Materials and methods}

\section{Composted materials}

Pre-hydrolysed hair from the leather manufacturing industry was obtained from the company Igualadina de Depuració i Recuperació S.L. (Igualada, Spain), which is in charge of the management of wastewater and solid waste generated in the leather manufacturing industry of the area. Briefly, hair wastes are produced when cow hide is treated sequentially for a total period of 24 hours with: 1) calcium hydroxide $(1.3 \%)$ and sodium hydroxide $(0.3 \%), 2)$ sodium hydrosulfide $(0.4 \%)$ in alkaline conditions ( $\mathrm{pH} 13)$ and 3 ) sodium sulfide (0.7\%) under alkaline conditions $(\mathrm{pH} 13)$. After this treatment, pre-hydrolysed hair is separated from the hide and then collected by filtration. Digested sewage sludge was obtained from the wastewater treatment plant of Cambrils (Spain), which is usually processed at the composting plant of Jorba (Barcelona). Pruning wastes from the vicinity of Igualada (Spain) were used as bulking agent, since this is the typical bulking agent used in the composting plant of Jorba. Table 1 shows the main characteristics of the wastes composted.

\section{Preliminary composting experiments}

Laboratory-scale experiments were done using 4.5 L Dewar® vessels conditioned for static composting and in a $100 \mathrm{~L}$ static composter. A detailed description of these composters can be found elsewhere (Gea et al. 2005). In these reactors hair waste was composted on its own, mixed with pruning wastes in a 1:1 volumetric 
ratio, and in a tertiary mixture prepared as follows: sewage sludge and hair waste were mixed first (1:1, 1:2 and 1:4 hair:sludge weight ratios were assayed) and combined then with pruning wastes in a 1:1 volumetric ratio..

\section{Co-composting experiment at field scale}

Composting was carried out at the composting plant of Jorba (Spain). A composting pile was built by mixing $10 \mathrm{t}$ of hair wastes and $10 \mathrm{t}$ of sewage sludge. This mixture was then blended with shredded pruning wastes in a 1:1 volumetric ratio. The pile was built on a slopped concrete floor and left in the open. It was covered from rain according to the normal operation of the plant. Approximate dimensions of the pile were: base: $2 \mathrm{~m}$; height: $1.5 \mathrm{~m}$; length: $10 \mathrm{~m}$, in a trapezoidal shape. The composting experiment lasted from the $30^{\text {th }}$ November of 2004 to the $16^{\text {th }}$ February of 2005 (80 days). The pile was turned weekly using a Backhus Model 15.50 turner. Water was added to the pile on days 44 and 58 to ensure moisture content above $40 \%$.

Pile core temperature and oxygen content were measured in situ at $100 \mathrm{~cm}$ depth in 4 points of the pile. Temperature and oxygen values are presented as average values with the standard deviation value as error bar. Temperature was measured with a portable Pt-100 sensor (Delta Ohm HD9214) and oxygen concentration was measured with a portable $\mathrm{O}_{2}$ detector (Oxy-ToxiRAE, RAE) connected to a portable aspiration pump.

Respiration tests 
Static respiration indices were determined using a previously described respirometer (Barrena et al. 2005). This respirometer was built according to a model previously described (lanotti et al. 1993) and following the modifications and recommendations given by the U.S. Department of Agriculture and U.S. Composting Council (U.S. Department of Agriculture and U.S. Composting Council 2001). Results of the static respiration index $(\mathrm{RI})$ measured at $37^{\circ} \mathrm{C}$ of different integrated samples are presented as an average of three replicates. The standard deviation value is also presented.

\section{FAS measurements}

Free Air Space (FAS) was measured on an integrated sample using an air pycnometer based on the works of McCartney and Chen (2001) and Agnew et al. (2003).

\section{Analytical Methods}

Moisture content, dry matter content, organic matter content, $\mathrm{pH}$, electrical conductivity, Kjeldahl nitrogen, ammonium nitrogen $\left(\mathrm{N}-\mathrm{NH}_{4}{ }^{+}\right), \mathrm{C} / \mathrm{N}$ ratio and Rottegrade self-heating test were determined according to the standard procedures (U.S. Department of Agriculture and U.S. Composting Council 2001). These parameters were analyzed in the laboratory after extracting a representative solid sample of the pile. For this purpose, 4 equidistant points of the pile (two for each side of the pile at a medium height of the pile) were sampled extracting about $5 \mathrm{~L}$ of compost at each point. The total volume of sample (about $20 \mathrm{~L}$ ) was 
manually mixed and a final volume of $2 \mathrm{~L}(1 \mathrm{~kg})$ was used to carry out the analytical procedures. An aliquot of this solid sample $(250 \mathrm{~mL}, 100-150 \mathrm{~g})$ was also used for the determination of the respiration index.

\section{Results and discussion}

Waste characteristics, initial mixture and preliminary composting experiments

Characteristics of the hair waste (Table 1) indicate that it may be effectively composted (Haug 1993). Particularly important are the high nitrogen content (12.1\%), and the low $\mathrm{C} / \mathrm{N}$ ratio (approximately 3 ). High nitrogen content may permit to obtain a valuable organic fertilizer. Based on these characteristics, composting was carried out at laboratory scale. However, results of experiments using hydrolysed hair alone and mixed only with pruning wastes were not satisfactory since the thermophilic range of temperatures was not reached indicating thus very low microbial activity. This was probably because the chemical treatment used for the hydrolysis of hair destroyed most of the microorganisms present in the material. Consequently, it was decided to look for a material that could act both as co-substrate and as inoculum for the degradation of the hair waste. Sewage sludge was thus chosen as complementary substrate on the basis of its characteristics, shown in Table 1, and also because it is a material easily available in most of the composting plants and contains a high amount and diversity of microbial flora. Composting experiments of hair waste mixed with sewage sludge and pruning wastes at the different weight ratios assayed indicated that they can 
be effectively composted regardless of the weight ratio. Good and similar compostabilities were found for all mixtures at both scales. Therefore, mixture with higher proportion of hair was chosen for the large scale experiments.

Characteristics of the composting mixture used for large scale experiments are presented in Table 1. As it can be seen, properties of the mixture seem to be optimal for composting, including a higher respiration index $\left(5.09 \mathrm{mg} \mathrm{O}_{2} \mathrm{~g}^{-1}\right.$ organic matter $\mathrm{h}^{-1}$ ) than that of hydrolysed hair alone.

\section{Field scale composting}

Evolution of temperature and interstitial oxygen

Temperature profile of the composting pile is shown in Figure 1a. From this Figure it can be observed that temperature was high throughout the experiment, even when ambient temperatures were below $0{ }^{\circ} \mathrm{C}$, and also that temperatures over $55^{\circ} \mathrm{C}$ were obtained for more than 70 days. As pile turnings were carried out once a week, it may be concluded that the material in its totality was exposed to temperatures in the thermophilic range. According to this, it can be said that this material meets the international requirements on compost sanitation, which are based on time-temperature conditions (U.S. Environmental Protection Agency 1995; European Commission 2001).

Oxygen content in interstitial air was low during the composting period (Figure 1a). Nevertheless, no offensive odours typically associated to the presence of anaerobic conditions were detected. Low oxygen content can be attributed to the high activity of the material which results in a high oxygen consumption (Gea et 
al. 2004). Moreover, it is clear that when temperature decreased at the end of the experiment (from day 70) oxygen level increased, both factors indicating a low biological activity due to the progressive diminution and exhaustion of biodegradable organic matter. Temperature rise and oxygen content clearly show the suitability of using sewage sludge as inoculum in the process of composting of hydrolysed hair. In fact, a number of studies on co-composting of wastes of complementary characteristics can be found in literature, although they are usually focused on adjusting some chemical properties such as moisture or $\mathrm{C} / \mathrm{N}$ ratio (Tiquia and Tam 2000; Huang et al. 2004; Meunchang et al. 2005); however, few studies are found on the use of such wastes as inoculum in the composting process.

\section{Chemical parameters}

Monitoring of moisture and total organic matter content along the process are presented in Figure 1b. Moisture followed the typical profile of a composting process, with a sharp decrease in the first weeks and a final stabilization, which coincides with the biological activity profile. Water was added at days 44 and 58 to ensure a moisture level over $40 \%$, which is often referred as a minimum value (Haug 1993). However, it must be pointed out that water shortage did not result in a significant decrease in the biological activity as it is shown by respiration index (Figure 2).

In reference to total organic matter content, the profile can then be considered typical of an effective composting process at full-scale (Mason et al. 
2004), with a marked decrease in the first weeks followed by a plateau. The high level of organic matter in the final compost $(57.8 \%$, Table 1$)$ is also an indicator of the compost quality.

\section{Stability indices}

Respiration index and self-heating test were also determined along the process. Both tests have been extensively used in the composting field to characterize the stability of composts (lanotti et al. 1993; Weppen 2002; Changa et al. 2003). Respirometry refers to the aerobic biological activity of the material and it is generally considered that values of respiration index below $1 \mathrm{mg} \mathrm{O}_{2} \mathrm{~g}$ organic matter ${ }^{-1} \mathrm{~h}^{-1}$ correspond to stable compost (California Compost Quality Council 2001). Self-heating test also gives information on the stability of a compost sample. It ranges from grade I (fresh material) to grade $\mathrm{V}$ (compost completely stable) (U.S. Department of Agriculture and U.S. Composting Council 2001).

Results of the respiration index and self-heating test obtained in the composting experiment are presented in Figure 2. Respiration index of the composting mixture shows an important decrease throughout the process. This agrees with the progressive stabilization of organic matter, confirming the fact that important oxygen consumption takes place in the first stage. At the same time, it is evident that respiration index is a valuable indicator of the biological activity at fullscale, which indicates a significant biodegradation of hair wastes given the initial respiration indices of the composted materials (respiration indices of sewage sludge, hair wastes and initial mixture were 6.68, 3.22 and $5.09 \mathrm{mg} \mathrm{O}_{2} \mathrm{~g}^{-1}$ organic 
matter $\mathrm{h}^{-1}$ respectively, Table 1$)$ and the final value $\left(0.83 \mathrm{mg} \mathrm{O}_{2} \mathrm{~g}\right.$ organic matter ${ }^{-1}$ $\mathrm{h}^{-1}$ ). This is of special interest at the end of the composting process (maturation stage). In this period, thermophilic temperatures result from the thermal properties of the compost (low heat transfer rates due to low thermal conductivity) and from the biological activity of the material. Respiration index is sensitive enough as to detect the decline in the biological activity of the material.

Results of self-heating grade (Figure 2) confirm the results obtained for the respiration index. Thus, it took 11 weeks for the composting material to become very stable (grade $\mathrm{V}$ ), which is a typical time in the windrow composting process (Haug 1993).

\section{Final compost characteristics}

Both self-heating test and respiration index of the final compost (Table 1) confirmed that the final compost can be considered stable (grade $\mathrm{V}$ and respiration index of $0.83 \mathrm{mg} \mathrm{O}_{2} \mathrm{~g}$ organic matter $^{-1} \mathrm{~h}^{-1}$, respectively). This is of special interest for the application of this compost to soil. However, specific plant growth tests would be required to assess the actual agronomical value of the compost. On the other hand, FAS slightly increases during the process to reach a final value of $63.5 \%$ (Table 1), whereas $\mathrm{pH}$ is relatively steady and electrical conductivity shows a marked trend to increase, as it is usual in composting processes due to organic matter mineralization (Guerra-Rodríguez et al. 2003).

In reference to nitrogen conservation, it must be borne in mind that the open windrow process does not allow to perform a nitrogen balance, since losses due to 
gas emissions are difficult to account. Nevertheless, contents of Kjeldahl nitrogen and $\mathrm{N}-\mathrm{NH}_{4}{ }^{+}$have been determined in some samples (Table 2). Kjeldahl nitrogen showed an important decrease at the beginning of the process (from day 0 to 27) and a progressive stabilization and conservation in the following weeks. In fact, some authors have proposed the use of the nitrogen losses as an indicator of the biological activity of the material, although it implies a loss of the agronomical value of compost (Liao et al. 1995). The final nitrogen content can be considered high when compared with compost produced from other wastes, such as organic fraction of municipal solid wastes or sewage sludge (Barrington et al. 2002). This is because hair waste has a higher content of nitrogen. This is one of the main indications that composting of hair residue results in a final product with potential agricultural value.

$\mathrm{N}-\mathrm{NH}_{4}{ }^{+}$increased considerably during the active stage of the process (from day 27 to 63 ) to end up in a progressive decrease at the end of the process. Final $\mathrm{N}-\mathrm{NH}_{4}{ }^{+}$value can be considered as high $(0.5 \%$, Table 2$)$ when compared with typical values for Spanish organic fraction of municipal solid wastes, around 0.1$0.2 \%$ (Grau, 2000). This results from the high nitrogen content of the hair waste. Nevertheless, it is probable that a final curing stage of the compost at mesophilic temperature would produce a transformation of $\mathrm{N}^{-\mathrm{NH}_{4}}{ }^{+}$to nitrate form via the nitrification process (Shi et al. 1999; Sánchez-Monedero et al. 2001).

In any case, the nitrogen and organic matter content confers this compost a high agronomical value, which can be properly used to recycle this material from the tannery industry. 


\section{Conclusions}

From the results obtained, it can be concluded that:

1) Hair wastes from the leather manufacturing industry can be successfully composted using sewage sludge as a co-substrate for inoculation. A 1:1 weight ratio mixture of hair wastes and sewage sludge has proven to be an adequate blend for the process when it is mixed with pruning wastes in a 1:1 volumetric ratio to provide the adequate porosity. A measure of porosity in form of FAS appears necessary to carry out composting experiments at full-scale with new mixtures.

2) Composting mixture reaches and maintains the thermophilic range of temperature long enough as to fulfil the international requirements on compost sanitation (U.S. Environmental Protection Agency 1995; European Commission 2001).

3) The compost obtained has a high nitrogen content and optimal grade of stability, which are key parameters for its utilization as an organic fertilizer. However, plant growth tests are still required to determine the actual agronomic value of the product.

4) The composting technology appears as a sustainable and environmentally friendly method to recycle one of the main solid wastes produced in the Spanish tannery industry.

\section{Acknowledgments}


The authors wish to thank the interest of Miquel Vila from Igualadina de Depuració i Recuperació S.L. in the development of this work, as well as the help received from the personnel of the composting plant of Jorba. Financial support was provided by Igualadina de Depuració i Recuperació S.L. and the Spanish Ministerio de Ciencia y Tecnología (Project REN2003-00823).

\section{References}

Agnew, J., J. Leonard, J. Feddes and Y. Feng. 2003. A modified air pycnometer for compost air volume and density determination. Canadian Biosystems Engineering, 45:27-35.

AllCA. 2005. Research Association of the Leather Industries and Annexes. URL: http://www.aiica.com/index_english.htm

Barrena, R., F. Vázquez, M.A. Gordillo, M.T. Gea and A. Sánchez. 2005. Respirometric Assays at Fixed and Process Temperatures to Monitor Composting Process. Bioresource Technology, 96:1153-1159.

Barrington, S., D. Choiniere, M. Trigui, and W. Knight. 2002. Effect of carbon source on compost nitrogen and carbon losses. Bioresource Technology, 83:189-194.

Boshoff, G., J. Duncan and P.D. Rose. 2004. Tannery effluent as a carbon source for biological sulphate reduction. Water Research, 38:2651-2658. 
Cabeza L.F., M.M. Taylor, G.L. DiMaio, E.M. Brown, W.N. Marmer, R. Carrió, P.J. Celma and J. Cot. 1998. Processing of leather waste: pilot scale studies on chrome shavings. Isolation of potentially valuable protein products and chromium. Waste Management, 18:211-218.

California Compost Quality Council. 2001. CCQC-Compost Maturity Index. URL: http://www.crra.com/ccqc/ccqchome.htm

Changa, C.M., P. Wang, M.E. Watson, H.A.J. Hoitink and F.C. Michel. 2003. Assessment of the reliability of a commercial maturity test kit for composted manures. Compost Science and Utilization, 11:125-143.

Gea, M.T., R. Barrena, A. Artola and A. Sánchez. 2004. Monitoring the Biological Activity of the Composting Process: Oxygen Uptake Rate (OUR), Respirometric Index (RI) and Respiratory Quotient (RQ). Biotechnology and Bioengineering, 88:520-527.

Gea, M.T., A. Artola, X. Sort and A. Sánchez. 2005. Composting of Wastes Produced in the Catalan Wine Industry. Compost Science and Utilization, in press.

Grau, J., A. Sánchez, X. Font and F. Aguilera. 2000. Windrow pile composting systems. Study of the composting plant of Jorba (Barcelona) (in Spanish). Ingeniería Química, 374:121-126.

Guerra-Rodríguez, E., M. Vázquez and M. Díaz-Raviña. 2003. Dynamics of the cocomposting of barley waste with liquid poultry manure. Journal of the Science of Food and Agriculture, 83:166-172. 
Euroleather. 2005. European Leather Industry. Statistics, Sectoral Data 2003. URL: http://www.euroleather.com/sector.htm

European Commission. 2001. Working document. Biological treatment of $\begin{array}{llll}\text { biowaste. } & \text { 2nd }\end{array}$ http://europa.eu.int/comm/environtment/waste/facts_en.htm

Farabegoli, G., A. Carucci, M. Majone and M. Rolle. 2004. Biological treatment of tannery wastewater in the presence of chromium. Journal of Environmental Management, 71:345-349.

Haug, R.T. 1993. The Practical Handbook of Compost Engineering. Lewis Publishers, Boca Raton, FL.

Huang, G.F., J.W.C. Wong, Q.T. Wua and B.B. Nagarb. 2004. Effect of C/N on composting of pig manure with sawdust. Waste Management, 24:805-813.

lannotti, D.A., T. Pang, B.L. Toth, D.L. Elwell, H.M. Keener and H.A.J. Hoitink. 1993. A quantitative respirometric method for monitoring compost stability. Compost Science and Utilization, 1:52-65.

Liao, P.H., A.C. May and S.T. Chieng. 1995. Monitoring process efficiency of a fullscale invessel system for composting fisheries wastes. Bioresource Technology, 54:159-163.

Mason, I.G., M.S. Mollah, M.F. Zhong and G.J. Manderson. 2004. Composting high moisture content bovine manure using passive aeration. Compost Science and Utilization, 12:249-267. 
McCartney, D. and H. Chen. 2001. Using a Biocell to measure effect of compressive settlement on free air space and microbial activity in windrow composting. Compost Science and Utilization, 9:285-302.

Meunchang, S., S. Panichsakpatanaa and R.W. Weaver. 2005. Co-composting of filter cake and bagasse: by-products from a sugar mill. Bioresource Technology, 96:437-442.

Murugananthan, M., G. Bhaskar Raju and S. Prabhakar. 2004. Separation of pollutants from tannery effluents by electro flotation. Separation and Purification Technology, 40:69-75.

Sánchez-Monedero, M.A., A. Roig, C. Paredes and M.P. Bernal. 2001. Nitrogen transformation during organic waste composting by the Rutgers system and its effects on $\mathrm{pH}, \mathrm{EC}$ and maturity of the composting mixtures. Bioresource Technology, 78:301-308.

Song, Z., C.J. Williams and R.G.J. Edyvean. 2004. Treatment of tannery wastewater by chemical coagulation. Desalination, 164:249-259.

Tiquia, S.M. and N.F.Y. Tam. 2000. Co-composting of spent pig litter and sludge with forced-aeration. Bioresource Technology, 72:1-7.

U.S. Department of Agriculture and U.S. Composting Council. 2001. Test methods for the examination of composting and compost. Edaphos International, Houston, TX.

U.S. Environmental Protection Agency. 1995. A Guide to the Biosolids Risk Assessments for the EPA Part 503 Rule. URL: http://www.epa.gov/owm/mtb/biosolids/503rule/ 
Vidal, G., J. Nieto, K. Cooman, M. Fajardo and C. Bornhardt. 2004. Unhairing effluents treated by an activated sludge system. Journal of Hazardous Materials, 112:143-149.

Wang, P., C.M. Changa, M.E. Watson, W.A. Dick, Y. Chen and H.A.J. Hoitink. 2004. Maturity indices for composted dairy and pig manures. Soil Biology and Biochemistry, 36:767-776.

Weppen, P. 2002. Determining compost maturity: evaluation of analytical properties. Compost Science and Utilization, 10:6-15.

Shi, W., Norton, J.M., Miller, B.E. and Pace, M.G. 1999. Effects of aeration and moisture during windrow composting on the nitrogen fertilizer values of dairy waste composts. Applied Soil Ecology, 11:17-28.

Wong, J.W.C., K.K. Ma, K.M. Fang and C. Cheung. 1999. Utilization of a manure compost for organic farming in Hong Kong. Bioresource Technology, 67:43-46. 
Tables

TABLE 1: Main characteristics of the wastes composted and of the final product.

\begin{tabular}{|c|c|c|c|c|}
\hline Parameter & $\begin{array}{l}\text { Sewage } \\
\text { sludge }\end{array}$ & $\begin{array}{c}\text { Hydrolysed } \\
\text { hair }\end{array}$ & Mixture* & $\begin{array}{c}\text { Final } \\
\text { product }\end{array}$ \\
\hline Moisture (\%) & 81.8 & 62.1 & 67.7 & 43.2 \\
\hline Dry Matter (\%) & 18.2 & 37.9 & 32.2 & 56.8 \\
\hline Organic Matter (\% dry basis) & 57.7 & 88.7 & 76.6 & 57.8 \\
\hline N-Kjeldhal (\% dry basis) & 2.5 & 12.1 & 8.5 & 5.6 \\
\hline $\mathrm{N}-\mathrm{NH}_{4}^{+}$(\% dry basis $)$ & 0.47 & 1.53 & 0.77 & 0.55 \\
\hline $\mathrm{C} / \mathrm{N}$ ratio & 13.0 & 3.3 & 5.0 & 6 \\
\hline $\mathrm{pH}$ & 8.1 & 8.8 & 8.1 & 8.4 \\
\hline Electrical conductivity (mS/cm) & 1.8 & 2.8 & 2.7 & 8.17 \\
\hline $\begin{array}{l}\text { Respiration index } \\
\left(\mathrm{mg} \mathrm{O}_{2} \mathrm{~g}^{-1} \text { organic matter } \mathrm{h}^{-1}\right)\end{array}$ & 6.68 & 3.22 & 5.09 & 0.83 \\
\hline Free Air Space (\%) & 42.3 & 45.3 & 54.4 & 63.5 \\
\hline Self-heating test & & & & V \\
\hline
\end{tabular}


TABLE 2: Kjeldahl nitrogen and $\mathrm{N}-\mathrm{NH}_{4}{ }^{+}$in some samples during the composting experiment.

\begin{tabular}{ccc}
\hline $\begin{array}{c}\text { Day of } \\
\text { process }\end{array}$ & $\begin{array}{c}\text { Kjeldahl } \\
\text { nitrogen } \\
\text { (\%, dry basis })\end{array}$ & $\begin{array}{c}\mathrm{N}^{-\mathrm{NH}_{4}{ }^{+}} \\
(\%, \text { dry basis })\end{array}$ \\
\hline 0 & 8.5 & 0.3 \\
27 & 4.9 & 1.2 \\
63 & 5.5 & 1.4 \\
78 & 5.6 & 0.5 \\
\hline
\end{tabular}




\section{Figure Legends}

Figure 1: Large scale co-composting of hair waste and sewage sludge with pruning wastes as bulking agent. a) Temperature and interstitial oxygen profiles. b) Moisture and organic matter content during the course of the experiment.

Figure 2: Respiration index and Self-heating test determined during the course of the composting experiment. 


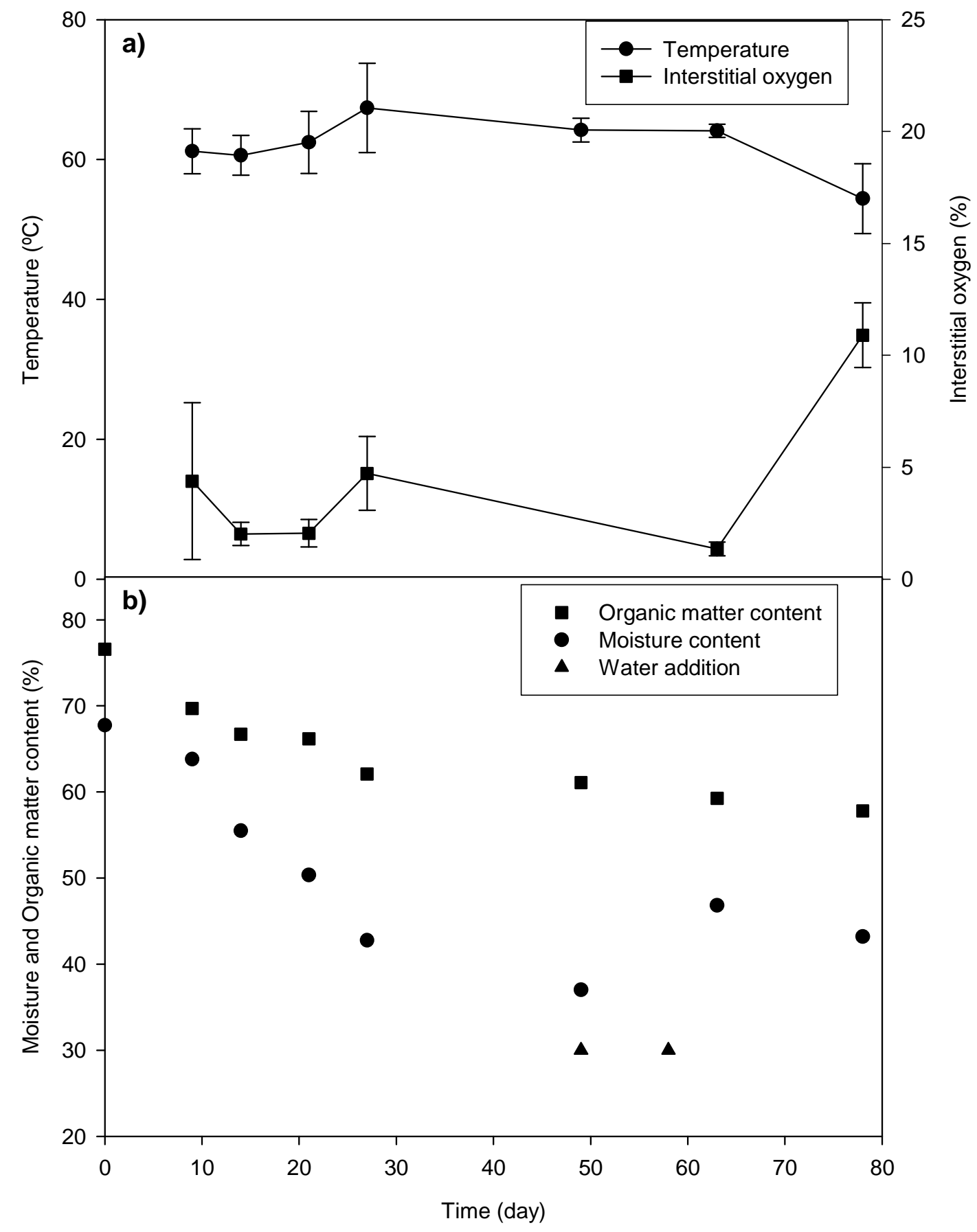


Figure 2: Barrena et al.

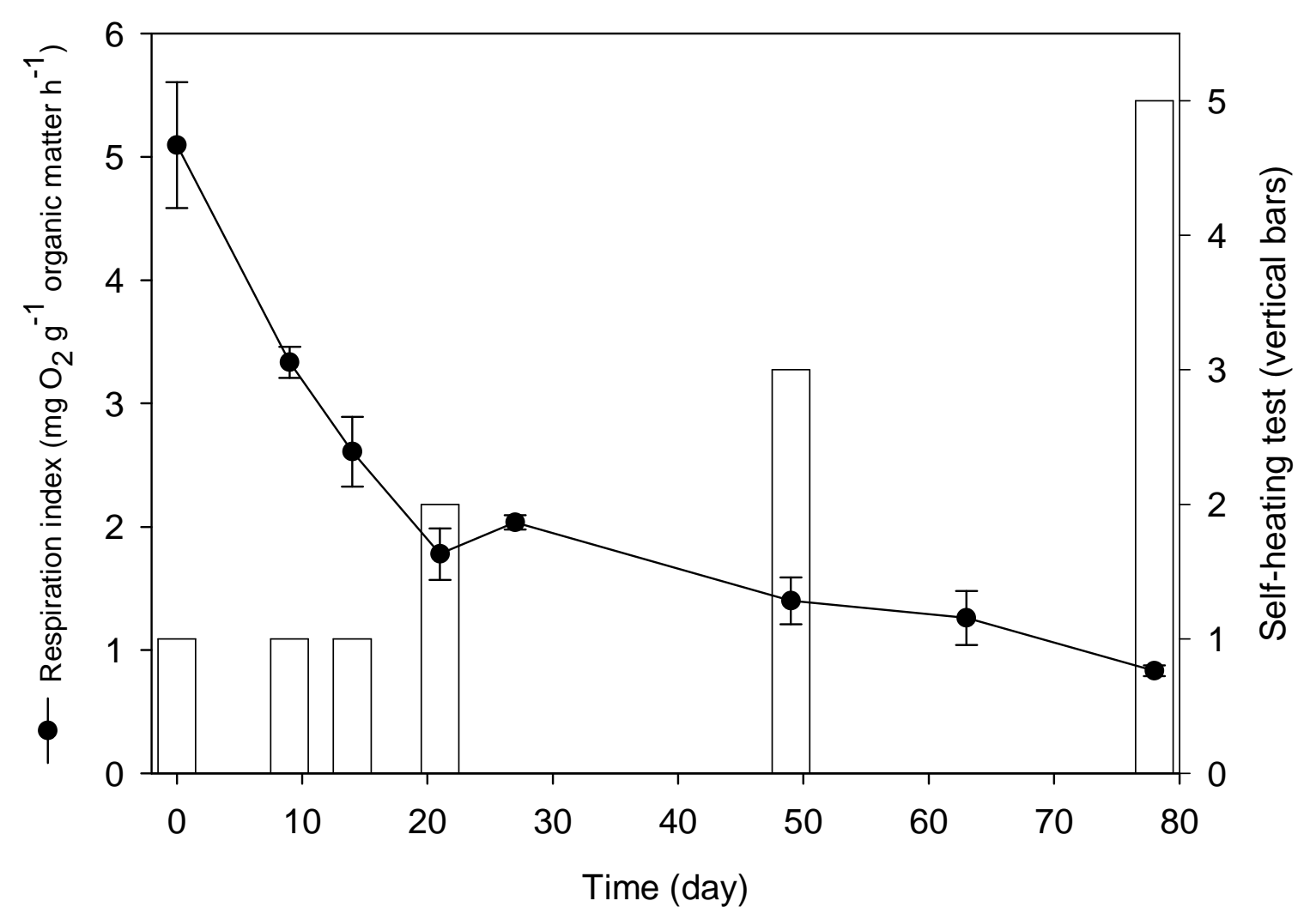

